\title{
EXPANSÃO DA EDUCAÇÃO SUPERIOR NO BRASIL: LIMITES E POSSIBILIDADES
}

\author{
Aparecida da Silva Xavier Barros*
}

RESUMO: Este estudo retrata e discute a distribuição e ampliação da Educação Superior no Brasil. A análise de dados estatísticos, artigos, legislação e matérias jornalísticas revela o cenário atual: percentual reduzido da populaçáo de 18 a 24 anos que frequenta esse nível de educaçáo e crescimento da oferta de vagas, sobretudo no sistema superior privado. A nossa reflexão se pauta nas políticas públicas direcionadas para a expansão e democratização da Educação Superior, procurando destacar os principais avanços. Temos como pressuposto que o maior desafio para a elevação geral do nível de escolaridade da população é o comprometimento do Estado, do Sistema Nacional de Educação e da sociedade civil com a melhoria da qualidade da Educaçáo Básica pública.

Palavras-chave: Expansão da educação superior; Políticas de democratizaçáo do acesso ao ensino superior; Qualidade da educação básica pública.

\section{EXPANSION OF HIGHER EDUCATION IN BRAZIL: LIMITS AND POSSIBILITIES}

ABSTRACT: This study portrays and discusses the distribution and expansion of higher education in Brazil. The analysis of statistical data, articles, laws and news articles reveals the current scenario: a reduced percentage in the 18 to 24-year-old population attending higher education and the growth in the provision of places, especially in the private higher education system. Our reflection is guided by public policies for the expansion and democratization of higher education, seeking to highlight the main advances. We assume that the biggest challenge for the overall rise of the population's schooling level is the commitment - from the State, the National System of Education and the civil society -, to the improvement of basic public education quality.

Keywords: Expansion of higher education; Democratization policies for the access to higher education; Quality of public basic education.

\footnotetext{
* Secretaria Estadual de Educação de Pernambuco, Programa de Educação Integral, Bezerros, PE., Brasil. E-mail de contato: aparecidaxbarros@hotmail.com.
} 


\section{L'EXPANSION DE L'ENSEIGNEMENT SUPÉRIEUR AU BRÉSIL: LIMITES ET POSSIBILITÉS}

RÉSUMÉ: Cette étude décrit et discute la distribution et l'expansion de l'enseignement supérieur au Brésil. L'analyse des données statistiques, des articles, de la législation et des matériels journalistiques révèle le scénario actuel: la baisse du pourcentage de la population entre 18-24 ans qui fréquente l'enseignement supérieur et la croissance de l'offre de postes vacants, notamment dans l'enseignement supérieur privé. Notre réflexion basée sur les politiques publiques destinées à l'expansion et à la démocratisation de l'enseignement supérieur qui cherchent à mettre en évidence les essors plus remarquables. Nous avons supposé que le principal défi pour le niveau d'instruction élevé de la population en général est l'engagement de l'État, du système d'éducation nationale et de la société pour améliorer la qualité de l'éducation de base.

Mots-clés: Expansion de l'enseignement supérieur; Politiques de démocratisation de l'accès à l'enseignement supérieur; Qualité de l'éducation de base.

\section{Introdução}

A

pesar do aumento significativo de Instituições de Ensino Superior (IES) e de matrículas ocorrido a partir dos anos de 1990, a taxa de escolarização líquida da população brasileira de 18 a 24 anos continua muito baixa: 14,4\%, segundo o Censo da Educação Superior de 2010. Além disso, 74\% de todas as matrículas de graduação estão no setor privado, respondendo o setor público por apenas 26\%. (INEP, 2010)

Iniciativas como o Programa Universidade para Todos (ProUni), o Programa de Financiamento Estudantil (Fies), o Programa de Apoio a Planos de Reestruturação e Expansão das Universidades Federais (Reuni), o aumento da oferta de cursos superiores a distância e as políticas de cotas vêm exercendo papel importante, porém limitado na redistribuição de oportunidades.

O objetivo principal deste estudo é o de contribuir para o debate acerca da expansão da educação superior brasileira, tendo como mote analítico as políticas de inclusão implementadas nas últimas décadas. Diante deste quadro, um importante desafio será brevemente analisado neste artigo: a melhoria da qualidade da Educação Básica pública e suas repercussões na Educação Superior. 


\section{A evolução das matrículas na educação superior, no período 2001-2010}

Em dez anos, as matrículas em cursos superiores (presenciais e a distância) mais que dobraram: de 3.036.113, em 2001, passaram para 6.379.299, em 2010. Como se pode observar na Tabela 1, o crescimento no número de matriculados foi considerável.

\section{Tabela 1}

Matrículas em cursos de graduação (presenciais e a distância) 2001 a 2010

\begin{tabular}{|c|c|c|c|c|c|c|c|c|c|c|c|}
\hline \multirow{2}{*}{ Ano } & \multirow{2}{*}{ Total } & \multicolumn{8}{|c|}{ Públicas } & \multicolumn{2}{|c|}{ Privadas } \\
\hline & & Total & $\%$ & Federal & $\%$ & Estadual & $\%$ & Municipal & $\%$ & Total & $\%$ \\
\hline 2001 & 3.036 .113 & 944.584 & 31,1 & 504.797 & 16,6 & 360.537 & 11,9 & 79.250 & 2,6 & 2.091 .529 & 68,9 \\
\hline 2002 & 3.520 .627 & 1.085 .977 & 30,8 & 543.598 & 15,4 & 437.927 & 12,4 & 104.452 & 3,0 & 2.434 .650 & 69,2 \\
\hline 2003 & 3.936 .933 & 1.176 .174 & 29,9 & 583.633 & 14,8 & 465.978 & 11,8 & 126.563 & 3,2 & 2.760 .759 & 70,1 \\
\hline 2004 & 4.223 .344 & 1.214 .317 & 28,8 & 592.705 & 14,0 & 489.529 & 11,6 & 132.083 & 3,1 & 3.009 .027 & 71,2 \\
\hline 2005 & 4.567 .798 & 1.246 .704 & 27,3 & 595.327 & 13,0 & 514.726 & 11,3 & 136.651 & 3,0 & 3.321 .094 & 72,7 \\
\hline 2006 & 4.883 .852 & 1.251 .365 & 25,6 & 607.180 & 12,4 & 502.826 & 10,3 & 141.359 & 2,9 & 3.632 .487 & 74,4 \\
\hline 2007 & 5.250 .147 & 1.335 .177 & 25,4 & 641.094 & 12,2 & 550.089 & 10,5 & 143.994 & 2,7 & 3.914 .970 & 74,6 \\
\hline 2008 & 5.808 .017 & 1.552 .953 & 26,7 & 698.319 & 12,0 & 710.175 & 12,2 & 144.459 & 2,5 & 4.255 .064 & 73,3 \\
\hline 2009 & 5.954 .021 & 1.523 .864 & 25,6 & 839.397 & 14,1 & 566.204 & 9,5 & 118.263 & 2,0 & 4.430 .157 & 74,4 \\
\hline 2010 & 6.379.299 & 1.643 .298 & 25,8 & 938.656 & 14,7 & 601.112 & 9,4 & 103.530 & 1,6 & 4.736 .001 & 74,2 \\
\hline
\end{tabular}

Fontes: INEP. Censo da Educação Superior 2010.

Apesar do total de matrículas (federais, estaduais, municipais e privadas) ter alcançado um crescimento de $110 \%$ nesse período, o fato é que a rede privada continua sendo a grande responsável pela Educaçáo Superior no país. Portanto, mesmo com o aumento de 944.584 para 1.643 .298 estudantes matriculados nas IES públicas, isso não foi suficiente para alterar a predominância da rede privada, que deteve $68,9 \%$ do total geral de matrículas registradas em 2001 e atingiu 74,2\% em 2010; enquanto nas redes públicas a participação caiu de 31,1\% para 25,8\%.

De acordo com Sguissardi (2006), a pequena expansão do setor público e o grande crescimento do setor privado explicam-se, em grande medida, pela drástica redução do financiamento às IFES e pelas facilidades de criação de IES privadas, especialmente com finalidade de lucro. ${ }^{1}$

Acerca do referido aumento das matrículas no Ensino Superior público, a rede federal totalizava 504.797 matrículas em 2001; em 2010, atingiu 938.656 (crescimento de 85,9\%); nas IES estaduais, o quantitativo de matriculados na década em questão passou de 360.537 para 601.112 (expansão de 66,7\%); na rede municipal ${ }^{2}$, o aumento foi mais tímido (30,6\%): das 79.250 matrículas informadas em 2001, chegou a 103.530 em 2010. 
Quando verificamos o quantitativo de matrículas em cursos de graduação por regiāo geográfica, o Censo da Educação Superior 2010 mostrou que houve crescimento nas Regióes Norte, Nordeste e Centro-Oeste. Em contrapartida, houve queda nas Regióes Sudeste e Sul.

\section{Tabela 2}

Distribuição e participação percentual de matrículas em cursos de graduação presenciais por Região Geográfica - 2001 e 2010

\begin{tabular}{l|r|r|c|c|r|c}
\hline & \multicolumn{6}{|c}{ Matrículas - Cursos Presenciais } \\
\hline $\begin{array}{c}\text { Região } \\
\text { Geográfica }\end{array}$ & \multicolumn{1}{|c|}{$\mathbf{2 0 0 1}$} & \multicolumn{1}{c}{$\%$} & \% População $^{\mathbf{1}}$ & $\mathbf{2 0 1 0}$ & \multicolumn{1}{c}{$\%$} & \% População $^{\mathbf{2}}$ \\
\hline Brasil & 3.030 .754 & 100,0 & $\mathbf{1 0 0}$ & 5.449 .120 & 100,0 & $\mathbf{1 0 0}$ \\
Norte & 141.892 & 4,7 & 5,8 & 352.358 & 6,5 & 8,3 \\
Nordeste & 460.315 & 15,2 & 28,7 & 1.052 .161 & 19,3 & 27,8 \\
Sudeste & 1.566 .610 & 51,7 & 43,4 & 2.656 .231 & 48,7 & 42,1 \\
Sul & 601.588 & 19,8 & 15 & 893.130 & 16,4 & 14,4 \\
Centro Oeste & 260.349 & 8,6 & 7,1 & 495.240 & 9,1 & 7,4 \\
\hline
\end{tabular}

Fontes: INEP. Censo da Educação Superior 2010.

\section{Nota:}

(1) IBGE. Pnad 2001; (2) IBGE. Censo Demográfico 2010.

Conforme observado na Tabela 2, o número de alunos nas universidades e faculdades ainda está distante da proporção da população nas regiōes. As diferenças de acesso compóem o cenário geral do Ensino Superior brasileiro na modalidade presencial. De fato, a distribuição das matrículas dos cursos de graduação, no período citado, ratificam as disparidades, com maior concentração de matrículas na Região Sudeste $(48,7 \%)$ e baixo acesso na Região Norte, com apenas $6,5 \%$ das matrículas.

Em relação às matrículas conforme o curso escolhido, os dez mais procurados entre os anos 2005 e 2009 estão expostos na Tabela 3. Constatamos que houve uma maior concentração de estudantes em certas áreas específicas. Por um lado, isto significa que enquanto algumas áreas consideradas estratégicas para o país ainda enfrentam o problema da mão de obra qualificada ${ }^{3}$, outras colocam cada vez mais gente no mercado de trabalho; e, por outro, retratam que os cursos que oferecem mais vagas, geralmente, são programados para absorver uma grande parcela dos candidatos ao Ensino Superior, embora a formação oferecida seja de qualidade ${ }^{4}$ bastante variada. 


\section{Tabela 3}

Evolução do número de matrículas dos dez maiores cursos em número de matrículas, segundo a Classificação de Cursos - 2005 a 2009

\begin{tabular}{|c|c|c|c|c|c|c|}
\hline \multirow{2}{*}{ Cursos } & \multicolumn{5}{|c|}{ Ano } & \multirow{2}{*}{$\begin{array}{c}\Delta \% \\
{[2005-2009]}\end{array}$} \\
\hline & 2005 & 2006 & 2007 & 2008 & 2009 & \\
\hline Administração & 730.898 & 813.948 & 887.752 & 1.050 .704 & 1.102 .579 & 51 \\
\hline Direito & 565.705 & 589.351 & 613.950 & 638.741 & 651.730 & 15 \\
\hline Pedagogia & 441.659 & 465.267 & 492.493 & 536.204 & 573.898 & 30 \\
\hline Engenharia & 264.894 & 285.207 & 314.192 & 357.132 & 420.578 & 59 \\
\hline Enfermagem & 153.359 & 186.955 & 213.237 & 224.742 & 235.804 & 54 \\
\hline Ciências Contábeis & 175.205 & 180.792 & 203.136 & 238.081 & 235.274 & 34 \\
\hline Comunicação Social & 199.350 & 209.366 & 230.606 & 238.055 & 221.211 & 11 \\
\hline Letras & 198.782 & 201.283 & 202.383 & 220.322 & 194.990 & [2] \\
\hline Educação Física & 159.484 & 172.369 & 184.213 & 187.285 & 165.848 & 4 \\
\hline Ciências Biológicas & 112.773 & 126.788 & 133.575 & 144.384 & 152.830 & 36 \\
\hline
\end{tabular}

Fontes: INEP. Censo da Educação Superior 2009.

O problema da concentração por área de conhecimento também foi um traço marcante da educação superior no período 1994-2002, segundo relatou Valdemar Sguissardi (2006, p. 1029). De acordo com o estudioso,

No ano 2000 a área de ciências sociais aplicadas (administração, direito, contabilidade, negócios) concentrava $41,6 \%$ do total de matrículas. As IES privadas concentravam, nos cursos dessa área, $50,1 \%$ de suas matrículas, contra $24 \%$ nas federais e $20 \%$ nas estaduais. A área de educação concentrava outros $21,7 \%$ do total de vagas, restando apenas cerca de $37 \%$ das vagas para todas as demais áreas do conhecimento. Essa concentração verifica-se em especial no setor privado, em razão, por hipótese, dos baixos investimentos exigidos e dos altos retornos financeiros. As áreas que requerem maiores investimentos, como as de engenharia, saúde, entre outras, tendem a ser majoritariamente atendidas pelo setor público.

Ao considerarmos as matrículas por turno, o censo observado mostra que o atendimento noturno foi predominante ao longo do período 2000/2010. As matrículas presenciais representavam 56,1\% do total em 2000, chegando a $63,5 \%$, em 2010. Ressalte-se, porém, que enquanto as IES privadas e municipais apresentaram maior participação na oferta de cursos noturnos, diferentemente delas, as IES federais e estaduais concentraram o atendimento no período diurno (visualizar o Gráfico 1). 


\section{Gráfico 1}

Evolução da participação de matrículas dos cursos presenciais por

Turno e Categoria Administrativa - 2000 a 2010

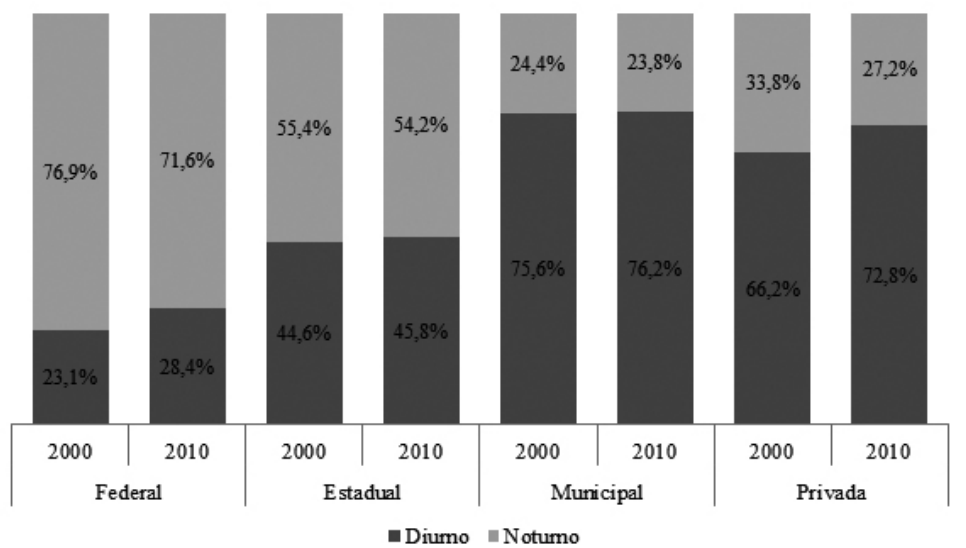

Fontes: INEP. Censo da Educação Superior 2010.

Nas instituiçóes públicas estaduais e federais, a pequena oferta de cursos noturnos indica a necessidade de um esforço maior para ampliar as oportunidades de acesso. Por sua vez, as taxas elevadas de matrículas nos cursos noturnos privados e municipais apontam para um problema bastante complexo. Por várias razões, a expansão da Educação Superior pela via privada e municipal apresenta dificuldades para corrigir a distribuição desigual dos bens educacionais. Nas palavras de Oliveira e Bittar (2010, p. 12-13),

A história do ensino noturno e, em particular, do ensino superior é bastante penosa no Brasil, sobretudo por duas razóes: de um lado, está associada ao ideal de democratização do acesso dos estudantes trabalhadores e, de outro, está relacionada com as condiçóes mais precárias de ensino e de aprendizagem, sobretudo em IES privadas que oferecem, em geral, cursos de qualidade bastante questionável. Além disso, essa história retrata a luta dos trabalhadores por oportunidades de estudar, mesmo trabalhando oito horas diárias ou mais. Os estudantes precisam, assim, conciliar trabalho e estudo, na maioria das vezes sem apoio financeiro do Estado, acreditando que o estudo poderá melhorar a sua condição de vida. Todavia, dado as condiçôes objetivas, boa parte dos estudantes do ensino superior noturno, sobretudo privado, acaba se tornando inadimplentes, evadindo ou mesmo concluindo um curso em condiçôes que não permitem agregar maior valor à formação e à qualificação para o mundo do traba- 
lho, assim como para o desenvolvimento pessoal e preparo para o exercício da cidadania.

Por fim, sendo a taxa de matrícula ${ }^{5}$ o principal indicador de inclusão no Ensino Superior, analisaremos, a partir daqui os principais limites e perspectivas de aumento equitativo desse acesso. Para melhor explicar este cenário, focalizaremos algumas políticas públicas e suas açóes de maior destaque, dentre elas: a ampliação de vagas públicas e a interiorização das IES - que tem ocorrido tanto no nível federal quanto no estadual; a ampliação do financiamento aos estudantes via novas políticas de financiamento, o estímulo à modalidade a distância, as políticas e os programas de inclusão e de ações afirmativas.

\section{A expansão da educação superior no Brasil: a demanda e a oferta de vagas nas universidades}

Para o sociólogo Simon Schwartzman (2006), o Ensino Médio brasileiro não forma pessoas em quantidade suficiente para alimentar a expansão que o Ensino Superior vem tendo. Por isso, mesmo levando em conta que não existe uma aderência perfeita da oferta atual à demanda existente (GARCIA, 2011), os números apresentados na Tabela 4 confirmam que desde 2003 há menos concluintes do Ensino Médio que vagas ofertadas no nível superior.

\section{Tabela 4}

Número de concluintes do Ensino Médio e de vagas ofertadas no Ensino Superior - 2001 a 2010

\begin{tabular}{l|c|c|c|c|c|c}
\hline \multirow{2}{*}{ Ano } & \multicolumn{2}{|c|}{ Concluintes do Ensino Médio } & \multicolumn{3}{c}{ Vagas oferecidas no Ensino Superior } \\
\cline { 2 - 7 } & Total & Pública & Privada & Total & Pública & Privada \\
\hline $\mathbf{2 0 0 1}$ & 1.836 .130 & 1.484 .173 & 351.957 & 1.408 .492 & 256.498 & 1.151 .994 \\
$\mathbf{2 0 0 2}$ & 1.855 .419 & 1.493 .436 & 361.983 & 1.773 .087 & 295.354 & 1.477 .733 \\
$\mathbf{2 0 0 3}$ & 1.884 .874 & 1.559 .256 & 325.618 & 2.002 .733 & 281.213 & 1.721 .520 \\
$\mathbf{2 0 0 4}$ & 1.851 .834 & 1.535 .761 & 316.073 & 2.320 .421 & 308.492 & 2.011 .929 \\
$\mathbf{2 0 0 5}$ & 1.879 .044 & 1.560 .182 & 318.862 & 2.435 .987 & 313.368 & 2.122 .619 \\
$\mathbf{2 0 0 6}$ & 1.858 .615 & 1.556 .545 & 302.070 & 2.629 .598 & 331.105 & 2.298 .493 \\
$\mathbf{2 0 0 7}$ & 1.749 .731 & 1.505 .121 & 244.610 & 2.823 .942 & 329.260 & 2.494 .682 \\
$\mathbf{2 0 0 8}$ & 1.761 .425 & 1.491 .812 & 269.613 & 2.985 .137 & 344.038 & 2.641 .099 \\
$\mathbf{2 0 0 9}$ & 1.797 .434 & 1.525 .289 & 272.145 & 3.164 .679 & 393.882 & 2.770 .797 \\
$\mathbf{2 0 1 0}$ & 1.793 .167 & 1.522 .379 & 270.788 & 3.120 .192 & 445.337 & 2.674 .855 \\
\hline
\end{tabular}

Fontes: Elaboração própria a partir dos Censos da Educação Superior (INEP, 2001-2010). 
Se, por um lado, os dados referentes ao total de concluintes do Ensino Médio confirmam que "[...] o sistema educacional brasileiro foi pouco eficiente em sua capacidade de produzir aprovados e, consequentemente, concluintes na idade correta [...]" (INEP, 2012, p. 12); por outro, sugerem que é preciso dar mais atenção aos problemas que afetam este nível de ensino, que até há pouco tempo náo era visto como essencial. Dentre as questóes mais graves, destacamos: o desinteresse dos estudantes pelo modelo de ensino praticado; a desistência dos alunos; a má formação do professor; os problemas de infraestrutura de muitas escolas; e o baixo nível de aprendizado, agravado pelo acúmulo de defasagens anteriores. Acerca deste último ponto, enfatizamos que a disponibilidade de indicadores de qualidade é bastante precária. Diferentemente do Ensino Fundamental, em que todas as escolas são avaliadas, os dados do Ensino Médio são feitos por amostragem, o que impossibilita a implantação e o acompanhamento eficiente das metas por escola e aluno. Portanto, não é à toa que esta etapa é considerada a pior da educação brasileira.

Em se tratando da oferta de vagas retratada na Tabela 4, verificamos que ao longo do período 2001-2010, manteve-se a tendência iniciada na década anterior, de crescimento da educação superior pela via privada, que passou a contar de forma significativa com apoio financeiro do governo. (OLIVEIRA, DOURADO, AMARAL, 2006) Desse modo, enquanto o setor público teve crescimento de $74 \%$ no quantitativo de vagas ofertadas, o setor privado alcançou $132 \%$ no mesmo período. O fato é que a partir de 1990, e com maior intensidade nos dois mandatos do Presidente Fernando Henrique Cardoso (1995-2002), as políticas para a educação superior se inserem no contexto de subordinação do país à economia global, à agenda neoliberal e às ideias disseminadas por organismos multilaterais, como Banco Mundial (BM), o Banco Interamericano do Desenvolvimento (BID) e a Organização Mundial do Comércio (OMC). Dentre outras coisas, tal lógica difundiu uma concepção de universidade calcada em princípios mercantilistas e produtivistas. Nesse sentido, a alternativa privada foi exaltada como a solução mais eficiente para acelerar a oferta de vagas. (SGUISSARDI, 2006)

Esse estímulo à expansão pela iniciativa privada provocou o rompimento com a ideia de universidade pautada na articulação entre ensino, pesquisa e extensão, o que permitiu a proliferação de cursos e instituiçóes privadas com padróes mínimos de qualidade. (MOEHLECKE; CATANI, 2006) Acrescente-se, ainda, que a grande diferença entre o setor público e privado não só pode ser percebida na oferta de vagas, mas também na ociosidade. Se, por exemplo, observarmos apenas os números dos três últimos anos, veremos que, em média, metade das vagas em cursos de graduação do setor privado não foi preenchida, conforme mostraremos na Tabela 5 .

Dentre os fatores que mais têm contribuído para a ociosidade e para a evasão, estão: a insuficiência de recursos financeiros para pagar mensalidades 
(AMARAL, 2008) e a diversificação e qualidade do sistema (características dos cursos: turno, área e modalidade - presencial e a distância; tipologia - bacharelados, tecnológicos e licenciaturas; e falta de condiçóes de permanência, tais como: transporte, moradia estudantil, recursos para a alimentação, assistência médica, bolsas de estudo e pesquisa, dentre outras), pontua Carvalho (2006b).

\section{Tabela 5}

Comparação entre o total de vagas oferecidas e ociosas - 2001 a 2010

\begin{tabular}{c|c|c|c}
\hline Ano & Vagas oferecidas & Vagas ociosas & $\%$ \\
\hline 2001 & 1.408 .492 & 371.802 & 26,39 \\
2002 & 1.773 .087 & 567.947 & 32,03 \\
2003 & 2.002 .733 & 739.779 & 36,93 \\
2004 & 2.320 .421 & 1.017 .311 & 43,84 \\
2005 & 2.435 .987 & 1.038 .706 & 42,64 \\
2006 & 2.629 .598 & 1.181 .089 & 44,91 \\
2007 & 2.823 .942 & 1.341 .987 & 47,52 \\
2008 & 2.985 .137 & 1.479 .318 & 49,55 \\
2009 & 3.164 .679 & 1.653 .291 & 52,2 \\
2010 & 3.120 .192 & 1.529 .980 & 49 \\
\hline
\end{tabular}

Fontes: Elaboração própria a partir dos Censos da Educação Superior (INEP, 2001-2010).

O número de vagas ociosas representa a diferença entre a quantidade de vagas com autorização do MEC para funcionar e o número de ingressantes nas IES. Das $371.802(26,39 \%)$ carteiras náo ocupadas em cursos presenciais das instituições públicas e privadas, em 2001, chegamos a 2010 com 1.529.980, ou seja, $49 \%$ de ociosidade. A maioria das vagas não utilizadas estava em IES privadas, onde esse quantitativo aumentou expressivamente: de 359.925, em 2001, atingiu o total de 1.493.205 vagas em 2010. Os quantitativos em graduaçáo presencial por categoria administrativa podem ser acompanhados na Tabela 6.

Na opinião de Reynaldo Fernandes, ex-presidente do Inep, a explicação para a "sobra" de vagas nas IES particulares é o fato de elas adotarem a estratégia de fazer "estoque" de vagas. A ex-secretária de Ensino Superior do MEC, Maria Paula Dallari Bucci, complementa: "[...] o processo de abertura de cursos era muito lento, por isso havia o interesse em deixar aprovadas mais vagas, antecipando-se, assim, à demanda [...]". (HARNIK, 2009, p. 01) E, de acordo com o consultor em Ensino Superior, Carlos Monteiro (CALGARO; POLO; TARGINO, 2009), uma das principais causas desta situação é a falta de planejamento destas instituiçóes. Por sua vez, o professor Jacques Schwartzman, da Universidade Federal de Minas Gerais (UFMG), pondera que não é possível vincular a questão unicamente à falta de planejamento ou à luta por atrair mais alunos. "Essas vagas não são totalmente 
ociosas. Em muitos casos, o que acontece é que cerca de 30\% dessas vagas é uma espécie de reserva técnica [...]." (HARNIK, 2009, p. 01)

\section{Tabela 6}

Número de vagas ociosas em graduação presencial por Categoria Administrativa - 2001 a 2010

\begin{tabular}{c|c|c|c}
\hline \multirow{2}{*}{ Ano } & \multicolumn{2}{|c|}{ Categoria Administrativa } & \multirow{2}{*}{ Total } \\
\cline { 2 - 3 } & Pública & Privada & \\
\hline 2001 & 11.877 & 359.925 & 371.802 \\
2002 & 14.863 & 553.084 & 567.947 \\
2003 & 14.132 & 725.647 & 739.779 \\
2004 & 21.250 & 996.061 & 1.017 .311 \\
2005 & 24.687 & 1.014 .019 & 1.038 .706 \\
2006 & 33.698 & 1.147 .391 & 1.181 .089 \\
2007 & 30.769 & 1.311 .218 & 1.341 .987 \\
2008 & 36.725 & 1.442 .593 & 1.479 .318 \\
2009 & 39.551 & 1.613 .740 & 1.653 .291 \\
2010 & 36.775 & 1.493 .205 & 1.529 .980 \\
\hline
\end{tabular}

Fontes: Elaboração própria a partir dos Censos da Educação Superior (INEP, 2001-2010).

No caso das IES públicas, o problema da sobra de vagas também é muito grave. De 2001 a 2010, a ociosidade mais que triplicou, passando de 11.877 vagas não ocupadas, em 2001, para 36.775, em 2010. Para Reynaldo Fernandes, a não ocupação nestas instituições faz parte de um processo natural de acomodaçâo dos universitários: "às vezes o aluno entra em um curso e resolve mudar [de graduação]".

Diante deste cenário, para conter os efeitos do esgotamento da expansão no Ensino Superior privado, o governo Lula [N.E.: Luiz Inácio Lula da Silva, 35․ Presidente da República Federativa do Brasil, período de 01 de janeiro de 2003 a 01 de janeiro de 2011), voltou suas ações para a sustentação financeira dos estabelecimentos existentes. Os principais mecanismos utilizados foram o ProUni e o Fies. E nas universidades federais, o Reuni, se propunha criar mais condiçóes para a ampliação do acesso e permanência na Educação Superior. Outras medidas como o aumento da oferta de cursos superiores a distância e a política de cotas também contribuíram para reverter os índices baixíssimos de inclusão neste nível de ensino.

Devido às limitaçóes de espaço, deixaremos de abordar algumas iniciativas igualmente importantes para a expansão e democratização da Educação Superior no Brasil, tais como a oferta de vagas em cursos de formação de professores de Educação Básica ${ }^{6}$ e o fortalecimento da Educação Tecnológica. ${ }^{7}$ 


\section{Políticas públicas de ampliação e democratização do acesso à educação superior brasileira}

A democratização pode apresentar significados diferentes e peculiares para cada indivíduo. Portanto, estes significados são decorrentes da ideologia dos sujeitos e da forma como eles compreendem a realidade política e social na qual estão inseridos. Nessa perspectiva, a partir de 2003, observa-se que diversos programas foram implementados para colaborar com a chamada democratização da Educação Superior no país. De certa maneira, apesar dos limites encontrados, tais medidas representaram um avanço para este nível de educação, dentre as quais destacamos:

\section{A. A ampliação do financiamento aos estudantes através do Programa Univer- sidade para Todos (ProUni) e do Fundo de Financiamento ao Estudante de Ensino Superior (Fies)}

O ProUni foi institucionalizado pela Lei 11.096, de 13 de janeiro de 2005. (MEC, 2011b) Acompanhado por um forte discurso de "justiça social" e com o apoio da sociedade civil, o programa representa para muitos estudiosos (MANCEBO, 2004; CATANI, HEY, GILIOLI, 2006; CARVALHO, 2006a, 2006b; ZAGO, 2006) a adesão do governo Lula às concepçôes neoliberais e às orientaçóes do Banco Mundial $^{9}$ à medida que intensifica o processo de estatização das vagas nas instituiçóes privadas por meio da transferência de recursos públicos ${ }^{10}$. Nesse sentido, tal medida foi bastante criticada por promover uma democratização "às avessas”.

Pesquisadores e analistas de políticas públicas também alertaram para a falta de mecanismos de controle democrático do Programa. Palavras fortes registraram esta questão: “[...] o que o ProUni faz é aumentar as isenções fiscais para IES privadas que, com poucas exceçóes, não prestam conta de como as usam, remuneram de forma ilegal seus sócios, não têm transparência na concessão de bolsas e maquiam balanços [...]", criticam Valente e Helene (2004, apud CATANI et al., 2006, p. 136). Sem contar que, em alguns casos, o acesso ao nível superior pela via privada compromete a formação do estudante. De acordo com cruzamento feito pela reportagem da Agência Estado (UOL, 2009) com dados do Índice Geral de Cursos (IGC) - anunciado pela primeira vez em setembro de 2008 e que permitem comparar o desempenho das IES - 22,9\% das que ofereceram vagas no ProUni apresentaram desempenho 1 e 2, o que pode ser traduzido como cursos com baixa ou baixíssima qualidade. Isso quer dizer que das 991 instituiçóes integrantes do programa em 2008, 227 tiveram desempenhos insatisfatórios. 
Segundo Carvalho (2006a, p. 09), “[...] no tocante ao caráter social, é adequada a afirmação de Catani e Gilioli (2005), segundo a qual o ProUni promove 'uma política pública de acesso, mas não de permanência e conclusão do curso' $[\ldots]$... Em outra obra, a referida autora ressalta que:

[...] o programa pode trazer o benefício simbólico do diploma àqueles que conseguirem permanecer no sistema e, talvez, uma chance real de ascensáo social para poucos que estudaram no seleto grupo de instituiçóes privadas de qualidade. Mas, para a maioria, cuja porta de entrada encontra-se em estabelecimentos lucrativos e com pouca tradição no setor educacional, o programa pode ser apenas uma ilusão e/ou uma promessa não cumprida. (CARVALHO, 2006b, p. 995-996)

Nesta mesma linha de pensamento, Corbucci (2004, p. 694), afirmou:

A principal crítica dirigida a essa iniciativa governamental é a de que os recursos que deixarão de ser arrecadados com a isenção de impostos poderiam ser aplicados na ampliação da oferta de vagas nas instituiçóes públicas. Portanto, para alguns críticos da proposta, o Estado estaria comprando vagas já existentes e ociosas, e ao mesmo tempo oferecendo um serviço de qualidade duvidosa.

A distribuiçãa ${ }^{11}$ das bolsas do ProUni se dá a partir dos resultados obtidos pelos estudantes no Exame Nacional do Ensino Médio (Enem). Para ter acesso às bolsas, é necessário que o candidato obtenha a nota mínima nesse exame, bem como possua renda per capita de até um salário mínimo e meio (para concorrer às bolsas integrais) ou renda de até três salários mínimos (para concorrer às bolsas parciais, de $50 \%$ e $25 \%$ ). Além disso, é requisito que o aluno tenha cursado o Ensino Médio integralmente ou parcialmente em escola pública ou, em escola particular, na condição de bolsista integral ou parcial. Professores da rede pública de ensino básico também podem concorrer às bolsas, mas, para isso, precisam comprovar efetivo exercício no quadro permanente da instituição e estar concorrendo a uma vaga em curso de licenciatura, normal superior ou pedagogia. Neste caso, a renda familiar por pessoa não é exigida. (MEC, 2011b)

$\mathrm{O}$ quantitativo de bolsas ofertadas tem crescido a cada semestre. De acordo com dados divulgados pelo Ministério da Educação (MEC, 2011c), em seu primeiro ano de funcionamento, o programa ofereceu 112.275 bolsas de estudo em 1.142 instituições de todo o país. Em 2006, segundo ano de funcionamento, ofertou 138.668 vagas, o que representou um aumento de 24\%. Em 2011, seis anos depois de iniciado o programa, são mais de 200 mil bolsistas beneficiados, conforme se pode observar no Gráfico 2: 


\section{Gráfico 2}

Bolsas do ProUni ofertadas por ano - Brasil, 2005 a 2011

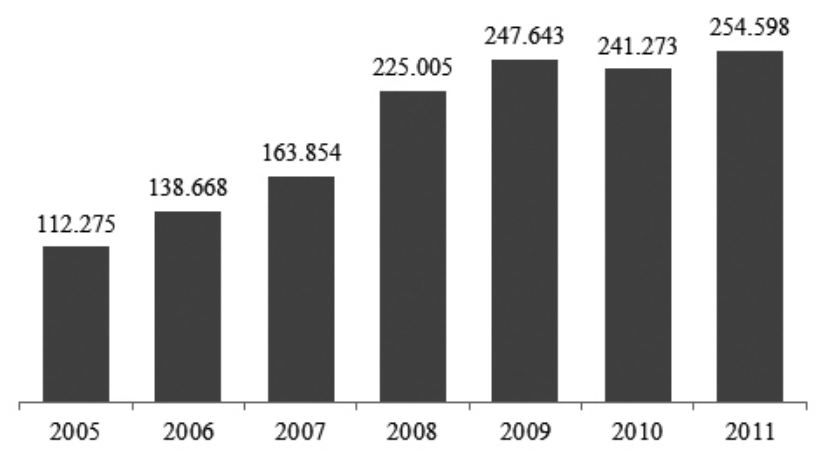

Fontes: Sisprouni-2005/2²011-MEC (2011c).

Todavia, de acordo com matéria de Rafael Targino (UOL, 2011a), uma em cada três bolsas oferecidas desde o começo do programa, em 2005, não foi preenchida. O total de bolsas ociosas chegou a 427.438 em seis anos, o que equivale a 33,1\% de todas elas. Até o primeiro semestre de 2011, o ProUni funcionava por meio de isenção fiscal em relação às bolsas oferecidas. Neste sentido, se a universidade oferecesse 100 bolsas, a redução nos impostos seria relativa a todas, mesmo que não fossem totalmente preenchidas. Isso demonstra que, neste período, o governo simplesmente deixou de arrecadar dinheiro. A reportagem afirma ainda que, em 2009, uma análise do Tribunal de Contas da União (TCU) estimou que pudesse ter sido perdido, só nos dois primeiros anos do programa, um valor em torno de $\mathrm{R} \$ 100$ milhóes.

Outra opção para atender, prioritariamente, estudantes que demonstrassem falta de condiçóes para custear sua formação superior havia sido criada em 1999. Trata-se do Fundo de Financiamento Estudantil (Fies). Para ter acesso aos benefícios, os estudantes devem estar regularmente matriculados em IES não gratuitas cadastradas no programa e com avaliação positiva nos processos conduzidos pelo MEC. Esta medida, criada para substituir o Programa de Crédito Educativo (PCE/Ceduc), tem atualmente, como agentes financeiros, a Caixa Econômica Federal e o Banco do Brasil. Em 2010, o Fundo Nacional de Desenvolvimento da Educação (FNDE) passou a ser o Agente Operador do Programa e, com o novo formato, os juros caíram de $9 \%$ para 3,4\% ao ano. Além disso, passou a ser permitido ao estudante solicitar o financiamento em qualquer período do ano. (MEC, 2011a) 
Bolsistas parciais do ProUni e estudantes que tenham renda per capita de até um salário mínimo e meio podem optar pelo Fundo de Garantia de Operações de Crédito Educativo (FGEDUC), ficando dispensados da exigência do fiador. Existem dois tipos de fiança: a convencional (prestada por até dois fiadores) e a solidária (garantia oferecida reciprocamente em grupo de três a cinco participantes financiados pelo Fies). Em 2010, foram firmados 75,9 mil contratos. Em 2011, o número saltou para 153,5 mil. (AGÊNCIA BRASIL. O GLOBO, 2013)

\section{B) A ampliação de vagas na Rede Federal}

A primeira fase de expansão do Ensino Superior federal, denominada de Expansão I, compreende os anos de 2003 a 2007. Neste período, foram criadas 08 universidades federais em diversos estados. E, após 2007, com a instituição do Programa de Apoio a Planos de Reestruturação e Expansão das Universidades Federais (Reuni), mais 06 surgiram, totalizando 14 universidades no período de 2003 a 2010 (Gráfico 3). Além disso, a expansão da referida rede também contou com a interiorização dos campi. Com isso, o número de municípios atendidos pelas universidades federais passou de 114 em 2003 para 237 no final de 2011. (MEC, 2011d)

O Reuni, instituído pelo Decreto no 6.096, de 24 de abril de 2007, é uma das ações que integram o Plano de Desenvolvimento da Educação (PDE), e tem como objetivo principal a criação de condiçôes para a ampliação do acesso e permanência do estudante na Educação Superior, no nível de graduação, bem como o melhor aproveitamento da estrutura física e dos recursos humanos existentes nas universidades federais. (BRASIL, 2007)

Dados do Relatório do Primeiro Ano - Reuni 2008 (MEC, 2009) mostram que das 542 universidades federais existentes ao final de 2007, 533 aderiram ao programa. Quanto ao número de vagas em cursos presenciais de graduação, estas totalizavam 132.451, em 2007, e, em 2008, foi atingido um total de 147.277 vagas, o que equivale a um aumento de 14.826 novas oportunidades de ingresso. Por sua vez, a Relação Aluno-Professor (RAP) em 2008 foi de 17,8 alunos por professor, o que aponta para o cumprimento da meta apresentada no Artigo $1^{\circ}$ do Decreto no 6.096 .

Entretanto, apesar das boas intençóes elencadas pelo programa, é prudente que novos estudos analisem as consequências desta política que procura "[...] estimular a adesão a um novo modelo de universidade e uma nova relação de trabalho com os professores [...]”. (LIMA; AZEVEDO; CATANI, 2008, p. 23) Neste sentido, é importante destacar que manifestações de resistência e críticas ao Reuni foram expressas por grupos estudantis, sindicatos e docentes das universidades federais. Para eles, esta política aponta para a massificação das universidades 
federais, não por ampliar o número de vagas nas universidades, mas por prever a elevação da taxa de conclusão média para noventa por cento e o aumento da relação aluno-professor na graduação (18 por 1).

\section{Gráfico 3}

A expansão da Rede Federal de Educação Superior Brasil - 2003 a 2010

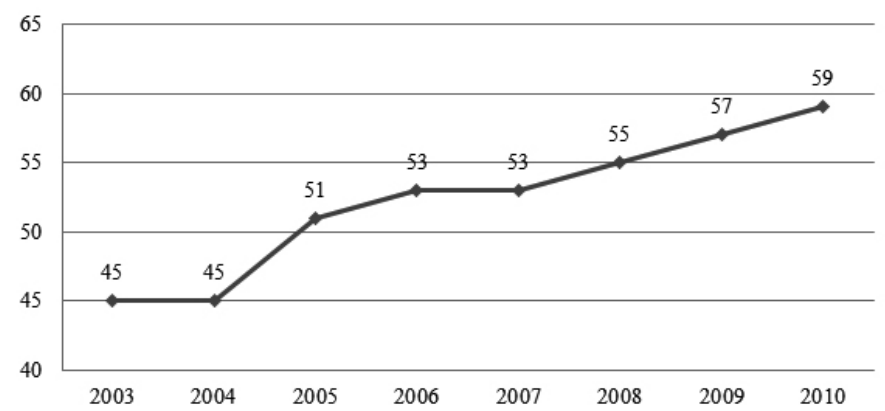

Fontes: Reuni/MEC (2011d).

Por fim, o mérito de tal iniciativa também é questionado pelos atrasos, projetos ruins e custos adicionais em obras das unidades novas ou ampliadas. A demora na conclusão atinge uma em cada quatro construçôes avaliadas, diz reportagem de Goulart e Maggi (2012). Apesar do orçamento crescente, o número de obras paralisadas do Reuni cresceu: foram 178 em 2012, ante 53 em 2011. Acerca desta questão, o sociólogo Simon Schwartzman (2006) disse à reportagem:

Essa política de expansão acelerada não obedeceu a nenhum plano ou avaliação cuidadosa sobre prioridades. Abriu-se instituiçốes onde não havia demanda, admitiu-se alunos antes de existirem os edifícios e instalações adequadas e forçou-se as universidades a criar cursos noturnos e contratar mais professores mesmo quando não havia candidatos qualificados

Contudo, consideramos que fazer uma explanação detalhada desta situação, requer uma análise mais apurada sobre os fatos, o que, neste momento, ultrapassa os limites de análise do presente texto.

\section{C) $\mathrm{O}$ estímulo à modalidade a distância}

Desde 2003, houve enorme crescimento da oferta de cursos a distância, predominantemente no setor privado. No entanto, com a criação da Universidade 
Aberta do Brasil (UAB), por meio de parceria entre instituições formadoras (IFES, CEFETs e IES Estaduais) e sistemas de ensino estaduais e municipais, vem crescendo a oferta de educação superior pública em diferentes regióes e municípios do país. A UAB foi instituída pelo Decreto no 5.800, de 08 de junho de 2006, com o intuito de oferecer cursos para camadas da população que têm dificuldades de acesso à formação universitária, através da modalidade da Educação a Distância (EaD). (BRASIL, 2006)

Há duas formas de ingresso no âmbito desse sistema: a primeira ocorre através do Plano Nacional de Formação de Professores de Educação Básica; a segunda se dá por meio da oferta destinada à demanda social. Nesse caso, as vagas são abertas a qualquer candidato que atenda aos pré-requisitos do curso e tenha sido aprovado em processo seletivo organizado pela instituição de ensino ofertante. Para o MEC (2011e), esta iniciativa contribui para a requalificação do professor em outras disciplinas, bem como minimiza a concentração de oferta de cursos de graduação nos grandes centros urbanos, evitando, assim, o fluxo migratório para as grandes cidades.

\section{Gráfico 4}

Percentuais de matrículas a distância por Grau Acadêmico - 2010

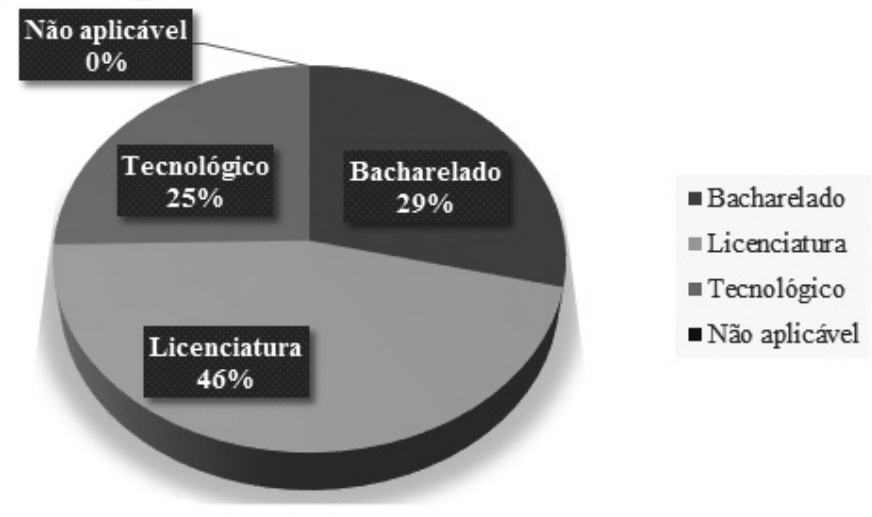

Fontes: INEP. Censo da Educação Superior 2010.

Nota:

* A categoria 'não aplicável' corresponde a Área Básica de Curso.

O MEC passou a coletar informaçóes sobre os cursos a distância apenas no ano 2000. Esta é uma modalidade que cresceu bastante nos últimos anos, atingindo $14,6 \%$ do total de matrículas. Os números são chamativos: 426.241 matrículas de licenciatura, 268.173 de bacharelado e 235.765 em cursos tecnológicos. (INEP, 2010) De acordo com o Ex-ministro da Educação, Fernando 
Haddad (UOL, 2011b), “[...] o EaD só não cresce mais em função do MEC. Não queremos que aconteça com a $\mathrm{EaD}$ aquilo que aconteceu nos anos $1990 \mathrm{com}$ a educação presencial - crescer descontrolado e com qualidade inferior [...]". Os percentuais representativos desses dados estão expostos no Gráfico 4.

Em relação a 2010, o Censo da Educação Superior 2011 (INEP, 2011) apontou que o crescimento observado nas matrículas a distância equivale a 12\% para o grau tecnológico (de 235.765 para 263.970 ), 11,6\% para o bacharelado (de 268.173 para 299.408) e 0,8\% para a licenciatura (de 426.241 para 429.549).

\section{D) As políticas de cotas}

Há vários anos um movimento surgiu, fora e dentro da universidade, para torná-la socialmente mais diversa e inclusiva. De acordo com Antônio Sérgio Guimarães (2010), o movimento negro foi o primeiro e, até bem pouco tempo, o único agente político a propor medidas concretas que ampliassem a democratização do Ensino Superior no Brasil. O tema das cotas raciais, nomeadamente, ganhou repercussão na mídia e provocou grandes polêmicas, principalmente, a partir dos anos 1990, quando se tornou motivo para debates acalorados e contestações, sobretudo, quanto ao seu fundamento legal.

Além da população, os intelectuais brasileiros também se dividiram no apoio ou na rejeiçâo às cotas denominadas "raciais", ponderando sobre aspectos sociais diversos. Guimarães (1999) argumentou que as políticas de cotas raciais ajudavam a desmascarar o racismo - que estaria no cerne de toda desigualdade econômica e cultural. Na visão de Sorj et al (2007, p.14), iniciativas como esta podem "[...] transformar a nação brasileira em uma nação dividida em duas metades - uma feita de brancos e a outra, de negros [...]".

Por sua vez, Yvonne Maggie e Peter Fry (2004), dentre outros autores, saíram em defesa de políticas universalistas, direcionadas aos economicamente desfavorecidos, pois acreditam que o principal problema existente na sociedade brasileira é social e não racial. Neste sentido, apontaram restrições à política baseada no critério "raça", tendo em vista que ela não garante a universalização dos direitos. Para estes estudiosos, promover a melhoria na qualidade da Educação Básica é a medida mais expressiva para que haja maior equidade no acesso ao Ensino Superior público.

Segundo Flávia Piovesan (2007) as ações afirmativas ${ }^{12}$ se constituem medidas especiais e temporárias, adotadas para aliviar e remediar as condiçóes resultantes de um passado discriminatório. Dito de outro modo, estas políticas são uma tentativa de eliminar a discriminação atual, e, sobretudo, anular os efeitos culturais e comportamentais da discriminação do passado. Lembrando que a dis- 
criminação, segundo esta autora, ocorre quando nós somos tratados como iguais, em situações diferentes, e de modo diferente, em situaçôes iguais.

Sobre a situação de desigualdade social e de oportunidades em que se encontram várias camadas da população de nosso país, há consenso de que ela ainda está longe de ser revertida. Esta afirmação pode ser comprovada nas estatísticas de acesso à educação e ao emprego, de renda, de acesso aos bens e serviços, e, também, no senso comum e na simples observação do dia a dia. O resultado de um estudo feito pelo Inep, a pedido do grupo UOL (CAPUCHINHO, 2013), com as informaçóes dos alunos que fizeram o Exame Nacional de Desempenho de Estudantes (Enade) aponta que os autodeclarados negros ainda são minoria entre os concluintes do Ensino Superior (Tabela 7).

\section{Tabela 7}

Percentual de pretos e pardos entre concluintes do Enade 2009 e 2010

\begin{tabular}{lc}
\hline \multicolumn{1}{c}{ Cursos } & \% de pretos e pardos \\
\hline Medicina & $2,66 \%$ \\
Design & $3,58 \%$ \\
Odontologia & $3,80 \%$ \\
Medicina Veterinária & $4,26 \%$ \\
Farmácia & $5,02 \%$ \\
Direito & $5,03 \%$ \\
Comunicação Social & $5,11 \%$ \\
Administração & $5,26 \%$ \\
Psicologia & $5,38 \%$ \\
Ciências Econômicas & $5,50 \%$ \\
\hline
\end{tabular}

Fontes: Dados do Enade 2009 e 2010 (CAPUCHINHO, 2013).

Dos universitários que fizeram Enade em 2010, apenas 6,13\% se declaravam pretos ou pardos. Em 2009, o índice foi ainda menor: 5,41\%. Na carreira de medicina, por exemplo, apenas 2,66\% dos concluintes, em 2010, eram pardos ou pretos. Na Tabela 7 , os dados referentes a outros cursos pesquisados retratam a fraca presença dessa camada da população em outras graduaçóes. Design e Odontologia, por exemplo, apresentam, respectivamente, o segundo e o terceiro pior resultado. (CAPUCHINHO, 2013)

Dada a ausência de uma lei nacional, as políticas de cotas foram objeto de diferenciados processos de discussão e aprovação em cada universidade. Entretanto, em 2012, foi sancionada a Lei no 12.711 , mais conhecida como a Lei de Cotas. Esta nova legislação criou uma única política de ação afirmativa: 
a reserva de $50 \%$ das vagas para estudantes que tenham cursado todo o ensino médio em escolas da rede pública, mas estas vagas serão subdivididas - metade será destinada para estudantes com renda familiar bruta igual ou inferior a um salário mínimo e meio per capita e metade para estudantes com renda familiar superior a um salário mínimo e meio. Em ambos os casos, também será levado em conta percentual mínimo correspondente ao da soma de pretos, pardos e indígenas no estado, de acordo com o último censo demográfico do Instituto Brasileiro de Geografia e Estatística (IBGE). (BRASIL, 2012)

As universidades e institutos federais terão quatro anos para implantar progressivamente o percentual de reserva de vagas estabelecido pela lei, mesmo aquelas que já adotam algum tipo de política afirmativa na seleção de estudantes. Portanto, o número de vagas reservadas deve crescer anualmente até 2016, a critério de cada instituição. Vale ressaltar também que, assim como já ocorre no ProUni e no Sistema de Seleção Unificada (Sisu), as vagas serão preenchidas a partir da autodeclaração, ou seja, o estudante informa, no momento da inscrição, a que grupo racial pertence.

A Lei de Cotas prevê que, no prazo de dez anos, seja realizada uma revisão do programa, a partir da avaliação do impacto das cotas no acesso de estudantes pretos, pardos, indígenas e alunos de escola pública. Todavia, se para o governo ainda é cedo para chegar a alguma conclusão, pesquisas, ainda preliminares, sugerem que as cotas não ocasionam o desastre acadêmico previsto por alguns. A investigação empreendida por Fábio Waltenberg e Márcia de Carvalho, da Universidade Federal Fluminense, com base no Enade de 2008, a partir das notas de 167.704 estudantes que concluíam a graduação, revela que os cotistas tiveram avaliaçóes $9 \%$ a $10 \%$ menores que os não cotistas, dependendo da instituição. Nesse caso, a defasagem não foi muito significativa. A título de comparação, basta dizer que estudantes do sexo feminino costumam ter notas $10 \%$ superiores às de colegas masculinos. (FOLHA DE SÃO PAULO, 2013)

De qualquer forma, é prudente aguardar um pouco mais para avaliar o resultado concreto das políticas adotadas. Contudo, cabe ao governo, à sociedade e à academia fazer um acompanhamento cuidadoso dessas variáveis.

\section{O desafio de melhorar a qualidade da educação básica pública}

Para um melhor entendimento sobre a ampliação do acesso de estudantes ao ensino superior, é necessário também acrescentar à análise outro fator: a qualidade da formação dos egressos do Ensino Médio. Destacamos no Gráfico 5 o ritmo de crescimento dos inscritos e, também, de não ingressantes nos referidos anos. O quantitativo de inscrições é bastante elevado, pois, além dos concluintes 
do ano em questão, estão inclusos: os que já concluíram o Ensino Médio em anos anteriores, os que se inscreveram em mais de uma instituição, os que fizeram os exames por experiência, dentre outras situaçóes. Contudo, a média de $74 \%$ de não ingressantes indica que é urgente que se reflita não somente sobre a melhoria da qualidade da Educação Básica, mas, também, sobre sua repercussão na admissão ao Ensino Superior em vigor no país.

\section{Gráfico 5}

Comparação entre os percentuais de ingressos e de não ingressantes em IES - 2001 a 2010

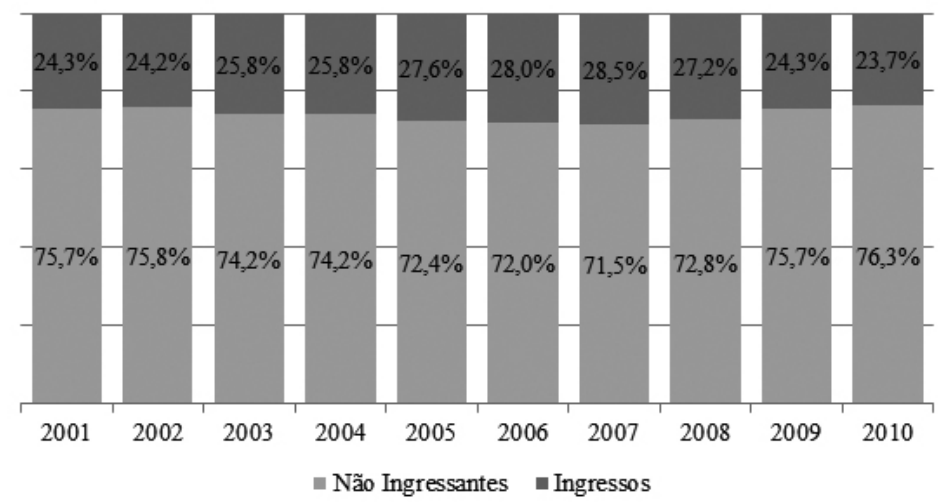

Fontes: Elaboração própria a partir dos dados retirados dos Censos da Educação Superior (INEP, 2001- 2010).

Comprovadamente, a grande maioria dos alunos que conclui o ensino médio possui sérias dificuldades de leitura, escrita e resolução de exercícios matemáticos elementares (Tabela 8). Sem uma formação científica mínima e com conhecimentos bastante fragmentados, a grande maioria encontra grandes dificuldades para conseguir aprovação nos processos seletivos das universidades de melhor qualidade. Acerca da entrada e da conquista de um diploma de curso de nível superior por jovens das classes menos favorecidas, Oliveira e Bittar (2010, p. 7) afirmam:

O ingresso no ensino superior é certamente uma parte visível desse funil de seletividade social, perpassado por processos de seleção excludentes adotados pelas IES, especialmente as públicas. Processos que aniquilam o ideário, o sonho, a igualdade real de oportunidade dos estudantes que buscam, no ensino superior, uma oportunidade de conquistar um espaço na carreira acadêmica e profissional. O esforço é ainda maior para os estudantes universitários que estão matriculados nos cursos noturnos, pois, para a grande maioria, isso acontece depois de uma jornada de 
trabalho diária de oito horas. A frustração pode vir de várias formas nessa trajetória: evadir-se por não conseguir pagar as mensalidades; não acompanhar o curso devido à fragilidade da formação anterior; concluir o curso e descobrir que pouco ou quase nada foi agregado de valor à formação, devido a qualidade do curso; não conseguir inserir-se profissionalmente no mercado de trabalho; e, finalmente, não conseguir a melhoria da qualidade de vida que tanto desejava.

\section{Tabela 8}

Percentuais de alunos com aprendizado adequado à sua série Brasil - 2001 a 2009

\begin{tabular}{c|c|c|c|c|c|c|c}
\hline \multirow{2}{*}{ Brasil } & \multicolumn{5}{|c|}{ Indicadores } & \multicolumn{2}{c}{ Metas } \\
\cline { 2 - 8 } & $\mathbf{2 0 0 1}$ & $\mathbf{2 0 0 3}$ & $\mathbf{2 0 0 5}$ & $\mathbf{2 0 0 7}$ & $\mathbf{2 0 0 9}$ & $\mathbf{2 0 0 9}$ & $\mathbf{2 0 2 1}$ \\
\hline $\mathbf{4}^{\mathbf{a}} / \mathbf{5}^{\circ} \mathbf{E F}$ - Port. & $23,70 \%$ & $25,60 \%$ & $26,60 \%$ & $27,90 \%$ & $34,20 \%$ & $36,60 \%$ & $70,00 \%$ \\
$\mathbf{4}^{\mathbf{a}} / \mathbf{5}^{\circ} \mathbf{E F}$ - Mat. & $14,90 \%$ & $15,10 \%$ & $18,70 \%$ & $23,70 \%$ & $32,60 \%$ & $29,10 \%$ & $70,00 \%$ \\
$\mathbf{8}^{\mathbf{a}} / \mathbf{9}^{\circ} \mathbf{E F}$ - Port. & $21,80 \%$ & $20,10 \%$ & $19,50 \%$ & $20,50 \%$ & $26,30 \%$ & $24,70 \%$ & $70,00 \%$ \\
$\mathbf{8}^{\mathbf{a}} / \mathbf{9}^{\circ} \mathbf{E F}$ - Mat. & $13,40 \%$ & $14,70 \%$ & $13,00 \%$ & $14,30 \%$ & $14,80 \%$ & $17,90 \%$ & $70,00 \%$ \\
$\mathbf{3}^{\mathbf{a}} \mathbf{E M}$ - Port. & $25,80 \%$ & $26,90 \%$ & $22,60 \%$ & $24,50 \%$ & $28,90 \%$ & $26,30 \%$ & $70,00 \%$ \\
$\mathbf{3}^{\mathbf{a}} \mathbf{E M}$ - Mat. & $11,60 \%$ & $12,80 \%$ & $10,90 \%$ & $9,80 \%$ & $11,00 \%$ & $14,30 \%$ & $70,00 \%$ \\
\hline
\end{tabular}

Fontes: Todos Pela Educação (2011), com adaptações.

De fato, as médias nacionais de aprendizado em Língua Portuguesa e Matemática são insuficientes. Os dados apresentados na Tabela 8 mostram que os nossos estudantes sabem menos que o esperado para as séries que cursam. Apesar disso, observamos que apenas os percentuais de desempenho dos alunos das séries iniciais ( $4^{\mathrm{a}}$ Série/5 Ano) do Ensino Fundamental apresentaram crescimento constante, tanto em Língua Portuguesa quanto em Matemática. Já os resultados dos estudantes das séries finais ( $8^{a}$ Série/9o Ano) do Ensino Fundamental, oscilaram bastante nos dois componentes avaliados, embora o aprendizado de Matemática tenha permanecido mais ou menos estagnado na casa dos $14 \%$. Por fim, os alunos da $3^{\text {a }}$ série do Ensino Médio alcançaram em Língua Portuguesa um desempenho um pouco melhor do que os estudantes da série anterior, mas também tiveram resultados ora mais altos, ora mais baixos. Em Matemática, os estudantes desta série apresentaram os piores resultados dentre todas que foram avaliadas.

Com base em documentos e contribuiçóes de especialistas, Barros (2012, p. 139-141), enumera algumas ações que são imprescindíveis para que tenhamos uma educaçáo básica pública de qualidade. Dentre esses desafios, aponta:

a) Melhorar o atendimento a crianças entre 4 e 5 anos. Dada a "[...] importância do estímulo cognitivo e social nesta etapa da vida para o desenvolvimento inte- 
gral e formação da base fundamental para o sucesso educacional [...]" (BRASIL, 2011, p. 32), é urgente reduzir o percentual de indivíduos dessa faixa etária, 19,9\%, que estão fora da escola. Veja-se o Relatório De olho nas Metas (TODOS PELA EDUCAÇÃO, 2011);

b) Aumentar a taxa de frequência dos estudantes no ensino médio e priorizar os investimentos públicos neste segmento de ensino, tanto em termos financeiros quanto técnico-pedagógicos. (BRASIL, 2011) De acordo com o movimento Todos Pela Educaçáo (2011), o país possui 16,7\% dos jovens com idade entre 15 e 17 anos fora do sistema de ensino;

c) Reduzir as taxas de repetência e evasão, bem como elevar a correspondência entre a idade apropriada e a etapa escolar. Apesar de o acesso ao ensino fundamental ser considerado universalizado, é visível a dificuldade de nossos jovens em dar prosseguimento aos estudos. São expressivos os percentuais de estudantes que não conseguem avançar: no caso do Ensino Fundamental: 43,4\% em 2005; 41,2\% em 2006; 39,5\% em 2007; 38,5\% em 2008; 36,6\% em 2009. Já no Ensino Médio as perdas são mais consideráveis: 60,2\% em 2005; 55,9\% em 2006; 55,1\% em 2007; 52,9\% em 2008; 49,8\% em 2009 (TODOS PELA EDUCAÇÃO, 2011);

d) Dotar as escolas de uma infraestrutura educacional que possa favorecer as condiçóes de aprendizagem dos estudantes. No Ensino Fundamental, por exemplo, $28 \%$ das escolas não possuem biblioteca, 36\% não estão equipadas com laboratório de informática e $40 \%$ não têm quadra de esportes. No Ensino Médio, itens imprescindíveis não fazem parte da realidade de muitas instituiçóes: laboratório de ciências (em 44\%), biblioteca (em 9,1\%) e laboratório de informática (em 7,5\%). Acerca disso, segundo o Observatório da Equidade do Conselho de Desenvolvimento Econômico e Social: "[...] ainda que não tenhamos indicadores da manutenção das instalaçóes escolares, não faltam reportagens mostrando a depreciação, mau funcionamento, depredação e até falta de segurança nas escolas [...]" (BRASIL, 2011, p. 25);

e) Elevar a qualidade de grande parte dos cursos de formação de professores e promover a melhoria dos salários e das condiçóes de trabalho daqueles que atuam na Educaçáo Básica nos estados e municípios. Os baixos salários, a excessiva carga horária e a quantidade de turmas assumidas por cada professor potencializam a perda de status social e de qualificação do trabalho docente (BRASIL, 2011);

f) Promover ações pedagógicas que tenham maior impacto no desempenho dos estudantes do Ensino Fundamental e do Ensino Médio em exames padronizados. Os resultados do Saeb apontam que nenhuma das séries avaliadas demonstrou aprendizado adequado para a respectiva série, seja em língua portuguesa, seja em matemática. (TODOS PELA EDUCAÇÃO, 2011) Em relação ao Ideb, temos uma diversidade de situaçóes relativas ao desempenho das escolas: em 2009 , apenas $3 \%$ das instituiçôes conseguiram resultados maiores ou iguais a 6,0 (equivalente às escolas de países mais desenvolvidos). Em contrapartida, uma em cada quatro escolas obteve desempenho menor que 3,0, e a maioria delas desempenho mediano, com notas entre 3,8 e 5,0. (BRASIL, 2011, p. 28) 


\section{Considerações Finais}

O Brasil tornou-se um país moderno e de economia emergente, embora marcado pela desigualdade social. No caso do acesso à Educação Superior, pode-se afirmar que várias iniciativas governamentais deram novo fôlego à expansão ocorrida neste nível de ensino. Contudo, mesmo acumulando crescimento de $110 \%$ no número de matrículas entre os anos 2001 e 2010, as estatísticas mostram que somente 8,8 das pessoas com idade entre 18 e 24 anos estavam matriculadas em cursos de graduação em 2001, passando para 14,4\%, em 2009. (IPEA, 2010b)

\section{Tabela 9}

Taxa de frequência líquida segundo a faixa etária de 18 a 24 anos Brasil e regióes - 2001 a 2009

\begin{tabular}{l|c|c|c|c|c|c|c|c|c}
\hline \multirow{2}{*}{ Brasil e regiões } & \multicolumn{10}{c}{ Anos - \% } \\
\cline { 2 - 11 } & 2001 & 2002 & 2003 & 2004 & 2005 & 2006 & 2007 & 2008 & 2009 \\
\hline Brasil & $\mathbf{8 , 8}$ & $\mathbf{9 , 8}$ & $\mathbf{1 0 , 5}$ & $\mathbf{1 0 , 4}$ & $\mathbf{1 1 , 1}$ & $\mathbf{1 2 , 4}$ & $\mathbf{1 2 , 9}$ & $\mathbf{1 3 , 6}$ & $\mathbf{1 4 , 4}$ \\
Norte & 5,2 & 6,7 & 6 & 5,6 & 7 & 7,7 & 9 & 9,9 & 11 \\
Nordeste & 5 & 5,1 & 5,7 & 5,8 & 6 & 7 & 7,5 & 8,2 & 9,2 \\
Sudeste & 10,7 & 11,9 & 12,6 & 12,9 & 13,6 & 15,4 & 16,3 & 16,4 & 16,8 \\
Sul & 12,5 & 13,7 & 15,8 & 15,2 & 16,1 & 17 & 16,6 & 18,6 & 19,2 \\
Centro-Oeste & 9,7 & 11,9 & 12,3 & 12,1 & 13,8 & 14,8 & 15,5 & 16,2 & 17,9 \\
\hline
\end{tabular}

Fontes: IPEA (2010b), com adaptaçōes.

O Plano Nacional de Educação - 2001 a 2010 (BRASIL, 2001) - traçou a meta de $30 \%$ das pessoas com idade entre 18 e 24 anos (taxa líquida) ${ }^{13}$ no sistema superior. Porém, a realidade mostra que estamos longe de alcançá-la (Tabela 9).

Outro ponto que chama a atenção na Tabela 9 são as diferenças regionais. As maiores disparidades de acesso ao Ensino Superior são verificadas especialmente entre o Sul e o Nordeste. Observa-se que esta última regiáo apresentou os piores resultados: 5,0\% e 9,2\% em 2001 e 2009, respectivamente. Assim, como as desigualdades de acesso são apontadas como um dos principais limitantes para o alcance da meta de taxa de frequência líquida de 33\% que consta no novo PNE (BRASIL, 2010), consideramos que o modelo de expansão adotado é insuficiente para romper com o processo excludente que perpassa a trajetória dos estudantes ao longo da Educação Básica, a qual é profundamente influenciada por suas condiçóes socioeconômicas. 
De acordo com o professor Mozart Neves Ramos, “[...] quando observamos esses números percebemos que ainda estamos engatinhando [...]”. (NUNES, 2011) Para ele, a baixa qualidade dos Ensinos Fundamental e Médio é uma das explicaçóes para o reduzido número de jovens brasileiros matriculados em universidades. Hoje está claro que a educação de baixa qualidade reduz as chances de nossos estudantes maximizarem o seu potencial, submetendo-os à marginalidade, a subempregos ou a trabalhos manuais de pouco valor agregado.

Os resultados apresentados ao longo deste texto apontam que as iniciativas governamentais são tímidas e consumirão muitas décadas até reduzir o nosso enorme déficit educacional. Nesse caso, é preciso que sejam desenvolvidas ações mais efetivas para alcançar níveis satisfatórios de qualidade na Educação Básica pública e, consequentemente, propiciar maior mobilidade profissional e social a milhóes de crianças e jovens.

\section{Notas}

1. Para maior aprofundamento dessa questão, ver também Sguissardi (2002, 2005).

2. Ao longo da década (2001-2010) as IES municipais apresentaram percentuais mínimos de participação no total de matrículas. Na opinião do Ex-secretário de Ensino Superior do MEC, Luiz Cláudio Costa, estas instituiçóes passaram por problemas relacionados ao financiamento e à infraestrutura. Logo, têm demonstrado mais dificuldades para atrair estudantes. (CIEGLINSKI, 2011)

3. O Comunicado no 41: Emprego e Oferta Qualificada de Mão de Obra no Brasil - Impactos do Crescimento Econômico Pós-crise (IPEA, 2010a) chama a atenção para o fato de que aproximadamente 6 milhóes de trabalhadores com baixa qualificação enfrentaram dificuldades para conseguir um lugar no mercado de trabalho em 2010.

4. Em 2009, 29 IES tiveram que desativar cursos ou foram descredenciadas pelo MEC por causa da baixa qualidade do ensino oferecido. Mais de 730 vagas de medicina e 20 mil de direito foram cortadas pelo mesmo motivo (O ESTADÃO, 2010). Em dezembro de 2012, o Ministro da Educação, Aloizio Mercadante, anunciou "[...] a suspensão de vestibulares de 207 cursos das áreas de engenharia, exatas, tecnologia e licenciatura (formação de professores), oferecidos por instituiçóes particulares e federais. A medida faz parte de novas regras criadas pelo Ministério da Educação (MEC) para coibir o funcionamento de faculdades de baixa qualidade [...]”. (WEBER, 2012)

5. É importante destacar que a taxa de matrícula pode ser formulada como taxa líquida ou taxa bruta. A taxa líquida corresponde à relação entre o número de pessoas de uma dada faixa etária (em geral, entre 18 e 24 anos) matriculadas no Ensino Superior e o total da população da faixa etária considerada. A taxa bruta, por sua vez, relaciona o número de matriculados (independentemente da idade) com o número de pessoas na faixa etária considerada. No Brasil, a taxa bruta é muito superior à taxa líquida. O Censo da Educação Superior, publicado pelo INEP (2011), mostrou que esse índice em 2010 era $27,8 \%$ para a taxa bruta e $14,6 \%$ para a taxa líquida.

6. Em 2009, por meio do Decreto n 6.755, de janeiro de 2009, o Ministério da Educaçáo (MEC) instituiu o Plano Nacional de Formação de Professores da Educação Básica (PARFOR), com a finalidade de organizar os planos estratégicos da formação inicial e continuada. O PARFOR tem como objetivo ampliar a oferta de vagas em cursos de licenciatura, sobretudo nas áreas de maior demanda: física, química, biologia, sociologia, filosofia, espanhol e inglês.

7. A expansão deste modelo institucional permitiu a ampliação da oferta de vagas gratuitas de nível 
superior, além de propiciar uma maior interiorização dos cursos e acelerar o processo de formação com cursos de menor duração.

8. O ProUni prevê a reserva de vagas para pretos, pardos e indígenas, bem como possibilita a participação de portadores de deficiência e de professores da rede pública para cursar licenciatura. De 2005 ao $1^{\circ}$ semestre de $201047 \%$ das bolsas foram ocupadas por afrodescendentes, ressalta o MEC (2011b).

9. "Para o Banco Mundial, esse nível de ensino não poderia ser tratado como um "bem estritamente público", em razão de suas condições de competitividade (oferta limitada), excluibilidade (pode-se obtê-lo mediante pagamento) e recusa (não é requerido por todos)", afirma Sguissardi (2006, p. 1038).

10. A Lei 11.096 determina que a Instituição que aderir ao ProUni ficará isenta, durante o período de vigência do termo de adesão, dos seguintes impostos e contribuiçôes: Imposto de Renda das Pessoas Jurídicas (IRPJ); Contribuição Social sobre o Lucro Líquido (CSLL); Contribuição Social para Financiamento da Seguridade Social (Cofins) e Contribuiçẫo para o Programa de Integração Social (PIS). (BRASIL, 2005)

11. O MEC recebe as inscriçóes para o programa por meio de um sistema disponível na internet, o Sisprouni. E uma comissão, constituída pelo referido Ministério, tem a responsabilidade de conferir os perfis dos candidatos, bem como divulgar a lista dos pré-classificados. Após a publicação da lista, os classificados procuram às instituições para as quais conseguiram o benefício para confirmar seus dados, levando a documentação comprobatória. Somente após a análise da documentação pela IES o benefício é liberado.

12. Nas últimas décadas, diferentes políticas e programas de ação afirmativa ocuparam o centro das discussóes sobre o acesso ao Ensino Superior brasileiro. As iniciativas, estabelecidas por leis ou resoluçóes dos conselhos universitários, tinham como finalidade atender a grupos específicos, tais como: afrodescendentes, egressos de escolas públicas e população de baixa renda. Entre os programas implementados, percebe-se uma grande variedade de critérios para definiçấo dos beneficiados. Os mais utilizados são: étnicos (direcionados à população indígena), raciais (voltados para os afrodescendentes), étnico-raciais (para afrodescendentes e indígenas), sociais (para egressos de escolas públicas el ou avaliados de acordo com a renda familiar), regionais (dão prioridade de ingresso a estudantes da região da universidade em questão), pontuam Guarnieri e Melo-Silva (2010).

13. A taxa de frequência líquida é adotada internacionalmente para mensurar o acesso à educação superior. Contudo, ela não incorpora aqueles estudantes que em algum momento frequentaram este nível de ensino - havendo concluído ou não -, bem como os que o frequentam em idade acima da faixa etária considerada adequada.

\section{Referências}

AGÊNCIA BRASIL. O GLOBO. MEC espera que Fies financie 400 mil estudantes em 2013. Jornal Extra, Rio de Janeiro, 27 de maio de 2013. Disponível em: <http:// extra.globo.com/noticias/educacao/mec-espera-que-fies-financie-400-mil-estudantes-em-2013-8508893.html\#ixzz2Xc4W31eY>. Acesso em: 02 jun. 2013.

AMARAL, N.C. Expansão-avaliaçáo-financiamento: tensôes e desafios da vinculação na educação superior brasileira. 31a. REUNIÃO ANUAL DA ANPED, Caxambu, MG, 19-22 out. 2008.

BARROS, A. S. X. Dimensóes do êxito de egressos de escolas públicas no processo seletivo para o curso de medicina da UFPE. 2012. 177p. Dissertação (Mestrado em 
Ciências da Educação) - Instituto de Educação. Universidade Lusófona de Humanidades e Tecnologias, Lisboa, Portugal.

BRASIL. Lei $\mathrm{n}^{\circ}$ 12.711, de 29 de agosto de 2012. Dispôe sobre o ingresso nas universidades federais e nas instituiçôes federais de ensino técnico de nível médio e dá outras providências. Diário Oficial [da] República Federativa do União, Brasília, DF, 30 de agosto de 2012. Disponível em: <http:/www.planalto.gov.br/ccivil_03/_Ato20112014/2012/Lei/L12711.htm>. Acesso em: 04 jun. 2013.

BRASIL. CÂMARA DOS DEPUTADOS. Projeto de Lei n.o 8.035, de 2010. Aprova o Plano Nacional de Educação para o decênio 2011-2020. Brasília: Câmara dos Deputados, 2011. Disponível em: <http://portal.mec.gov.br/index.php?option=com_ content\&id=16478\&Itemid=1107>. Acesso em: 02 fev. 2012.

BRASIL. As desigualdades na escolarização no Brasil: Relatório de observação no 4. 2. ed. Brasília: Presidência da República, Conselho de Desenvolvimento Econômico e Social CDES, 2011. 60p.

. Decreto no 6.096, de 24 de abril de 2007. Institui o Programa de Apoio a Planos de Reestruturação e Expansão das Universidades Federais - REUNI. Diário Oficial [da] República Federativa do Uniáo, Brasília, DF, 25 de abril de 2007. Disponível em: <http://www.planalto.gov.br/ccivil_03/_Ato2007-2010/2007/Decreto/D6096.htm>. Acesso em: 23 ago. 2011.

. Decreto no 5.800, de 08 de junho de 2006. Dispóe sobre o Sistema Universidade Aberta do Brasil - UAB. Diário Oficial [da] República Federativa do Uniáo, Brasília, DF, 09 de junho de 2006. Disponível em: <http://www.planalto.gov.br/ccivil_03/_ato20042006/2006/decreto/d5800.htm>. Acesso em: 12 ago. 2011.

. Lei n. 11.096, de 13 de janeiro de 2005. Institui o Programa Universidade Para Todos - ProUni, regula a atuação de entidades beneficentes de assistência social no ensino superior; altera a Lei no 10.891 , de 9 de julho de 2004, e dá outras providências. Diário Oficial [da] República Federativa do Uniāo, Brasília, DF, 14 jan. 2005. Disponível em: <http://www.planalto.gov.br/ccivil_03/_ato2004-2006/2005/lei/L11096.htm>. Acesso em: 02 ago. 2011.

BRASIL. Lei n. 10.172, de 09 de janeiro de 2001. Estabelece o Plano Nacional de Educação 2001-2010. Diário Oficial [da] República Federativa do União, Brasília, DF, 10 jan. 2001. Disponível em: <www.portal.mec.gov.br/arquivos/pdf/pne.pdf>. Acesso em: 02 jun. 2011.

CALGARO, F.; POLO, É.; TARGINO, R. Metade das vagas oferecidas nos vestibulares ficou ociosa em 2008. G1 Notícias, Rio de Janeiro, 27 nov. 2009. Disponível em: <http:// g1.globo.com/noticias/vestibular/0,,MUL1393910-5604,00-METADE+DAS+VAGAS +OFERECIDAS+NOS+VESTIBULARES+FICOU+OCIOSA+EM.html>. Acesso em: 04 ago. 2011.

CAPUCHINHO, C. No curso de medicina, apenas 2,7\% dos formandos são negros. UOL/Educaçáo, São Paulo, 20 maio 2013. Disponível em: < http://educacao.uol.com. 
$\mathrm{br} /$ noticias/2012/10/01/entenda-a-lei-de-cotas-nas-universidades-federais.htm>. Acesso em: 04/06/2013.

CARVALHO, C. H. A. Política para o ensino superior no Brasil (1995-2006): ruptura e continuidade nas relações entre público e privado. In: REUNIÁO ANUAL DA ANPED, 29, 2006, Anais... Caxambu: Anped, 2006a. Disponível em: <http://www.anped.org.br/ reunioes/29ra/trabalhos/trabalho/GT11-2337--In.pdf>. Acesso em: 07 ago. 2011.

CARVALHO, C. H. A. O PROUNI no governo Lula e o jogo político em torno do acesso ao Ensino Superior. Campinas, Educ. \& Soc, v. 27, n. 96, especial, outubro, p. 979-1000, 2006b. Disponível em: <http://www.cedes.unicamp.br>. Acesso em: 08 ago. 2011.

CATANI, A. M.; HEY, A. P.; GILIOLI, R. S. P. PROUNI: democratização do acesso às Instituições de Ensino Superior? Curitiba, Educar em Revista, n. 28, dez., p. 125-140, 2006.

CIEGLINSKI, A. Metade das vagas de ingresso no ensino superior do país sobrou em 2010. UOL/Educação, São Paulo, 11 nov. 2011. Disponível em: <http://noticias.uol. com.br/educacao/2011/11/11/metade-das-vagas-de-in. jhtm>. Acesso em: 19 dez. 2011.

CORBUCCI, P. R. Financiamento e Democratização do Acesso à Educaçáo Superior no Brasil: da deserção do Estado ao projeto de reforma. Educ. \& Soc., Campinas, v. 25, n.88, Especial, p.677-701, out. 2004.

FOLHA DE SÃO PAULO. Editorial: Cotas e notas. Disponível em: <http://www1.folha. uol.com.br/opiniao/2013/04/1270885-editorial-cotas-e-notas.shtml>. Acesso em: 08 jun. 2013.

GARCIA, M. Cenários e desafios para atingir 10 milhóes de alunos na Educação Superior. Disponível em: <www.abmes.org/abmes/public/arquivos/documentos/MGarcia_Artigo_10_milhoes.pdf>. Acesso em: 02 set. 2011.

GOULART, N; MAGGI, L. Reuni: CGU aponta 'sistemática de atrasos' em obras das universidades federais. São Paulo: Revista VEJA, 11 jul. 2012. Disponível em: <http:// veja.abril.com.br/noticia/educacao/reuni-cgu-aponta-\%E2\%80\%98sistematica-de atrasos\%E2\%80\%99-em-obras-das-universidades-federais>. Acesso em: 23 dez. 2012.

GUARNIERI, F. V.; MELO-SILVA, L. L. Perspectivas de estudantes em situação de vestibular sobre as cotas universitárias. Psicologia \& Sociedade, Florianópolis, v. 22, n. 3, 2010. Disponível em: <www.scielo.br/pdf/psoc/v22n3/v22n3a09.pdf>. Acesso em: 25 dez. 2012.

GUIMARÁES, A. S. A. Entrevista ao site da Ação Educativa sobre açôes afirmativas, realizada em 2010. Disponível em: <http://www.acaoeducativa.org.br/portal/index. php?option=com_content\&task=view\&id=633>. Acesso em: 12 out. 2012.

. Racismo e anti-racismo no Brasil. São Paulo: Fundação de Apoio à Universidade de São Paulo/Editora 34, 1999.

HARNIK, S. 49 em cem vagas do ensino superior do Brasil ficam ociosas, mostra censo. UOL/Educação, São Paulo, 27 nov. 2009. Disponível em: <http://educacao.uol.com.br/ ultnot/2009/11/27/ult105u8926.jhtm>. Acesso em: 18 abr. 2011. 
INEP. Censos Escolares da Educação Superior 2001-2010. Brasília, DF: Ministério da Educação/Instituto Nacional de Estudos e Pesquisas Educacionais Anísio Teixeira. Disponíveis em: <http://portal.inep.gov.br/superior-censosuperior-sinopse>. Acesso em: 05 mar. 2011.

Censo Escolar da Educação Básica 2012. Brasília, DF: Ministério da Educação/ Instituto Nacional de Estudos e Pesquisas Educacionais Anísio Teixeira, 2012. Disponível em: <http://download.inep.gov.br/educacao_basica/censo_escolar/resumos_tecnicos/ resumo_tecnico_censo_educacao_basica_2012.pdf>. Acesso em: 12 maio 2013.

. Censo Escolar da Educação Superior 2011. Brasília, DF: Ministério da Educação/ Instituto Nacional de Estudos e Pesquisas Educacionais Anísio Teixeira, 2011. Disponível em: <http://download.inep.gov.br/educacao_superior/censo_superior/resumo_tecnico/ resumo_tecnico_censo_educacao_superior_2011.pdf>. Acesso em: 02 nov. 2012.

. Censo Escolar da Educação Superior 2010. Brasília, DF: Ministério da Educação/ Instituto Nacional de Estudos e Pesquisas Educacionais Anísio Teixeira, 2010. Disponível em: <http://download.inep.gov.br/educacao_superior/censo_superior/resumo_tecnico/ resumo_tecnico_censo_educacao_superior_2010.pdf>. Acesso em: 19 out. 2011.

. Censo Escolar da Educação Superior 2009. Brasília, DF: Ministério da Educação/ Instituto Nacional de Estudos e Pesquisas Educacionais Anísio Teixeira, 2009. Disponível em: <http://download.inep.gov.br/download/superior/censo/2009/resumo_tecnico2009. pdf>. Acesso em: 02 mar. 2011.

IPEA. Emprego e oferta qualificada de mão de obra no Brasil: impactos do crescimento econômico pós-crise. Brasília, Comunicado do IPEA n. 41, março 2010a. Disponível em: <http://www.ipea.gov.br/sites/000/2/comunicado_presidencia/100310_ComunicaIpea_41_EmpregoOrfeta.pdf >. Acesso em: 03 ago. 2011.

. PNAD 2009: Primeiros Resultados. Situação da educação brasileira: avanços e problemas. Brasília, Comunicado do IPEA n. 66, novembro 2010b. Disponível em: <http:// www.ipea.gov.br/portal/images/stories/PDFs/101118_comunicadoipea66_apresentacao. pdf>. Acesso em: 04 ago. 2011.

LIMA, L. C.; AZEVEDO, M. L. N.; CATANI, A. M. O Processo de Bolonha, a Avaliação da Educação Superior e Algumas Consideraçôes sobre a Universidade Nova. Campinas, Avaliação, v. 13, n. 1, p. 7-36, mar. 2008.

LIMA, T. C. S.; MIOTO, R. C. T Procedimentos metodológicos na construçáo do conhecimento científico: a pesquisa bibliográfica. Florianópolis, Revista Katál, v. 10, n. esp., 2007, p. 37-45.

MAGGIE, Y.; FRY, P. A reserva de vagas para negros nas universidades brasileiras. São Paulo, Estudos Avançados, v. 18, n. 50, 2004, p. 67-80.

MANCEBO, D. Reforma universitária: reflexóes sobre a privatização e a mercantilização do conhecimento. Campinas, Educ. \& Soc., v. 25, n. 88, out. 2004.

MINISTÉRIO DA EDUCAÇÃO. (2011a). Programa de Financiamento Estudantil. Disponível em: <http://sisfiesportal.mec.gov.br/fies.html> Acesso em: 12 abr. 2011. 
MINISTÉRIO DA EDUCAÇÃO. (2011b). Portal ProUni. Disponível em: <http:// prouniportal.mec.gov.br> Acesso em: 19 out. 2011.

. (2011c). Sistema Informatizado do ProUni. Disponível em: <http://prouniportal.mec.gov.br> Acesso em: 19 jul. 2011.

. (2011d). Reuni - Expansão. Disponível em: <http://reuni.mec.gov.br/index. php?option $=$ com_content $\& v i e w=\operatorname{article} \& i d=100 \& I t e m i d=81>$. Acesso em: 24 nov. 2011.

. (2011e). Novo Portal UAB. Disponível em: <www.uab.capes.gov.br> Acesso em: 28 nov. 2011.

MINISTÉRIO DA EDUCAÇÃO. SECRETARIA DE EDUCAÇÃO SUPERIOR. Programa de Apoio a Planos de Reestruturação e Expansão das Universidades Federais. Reuni 2008 - Relatório de Primeiro Ano, 30 de outubro de 2009. Disponível em: <http://reuni. mec.gov.br/index. php?option $=$ com_content $\& v i e w=\operatorname{article} \& i d=25 \& I t e m i d=28>$. Acesso em: 23/04/2011.

MOEHLECKE, S.; CATANI, A. M. Reforma e Expansão do Acesso ao Ensino Superior: balanço e proposiçôes. In: Política para as Instituiçôes Federais de Ensino Superior (Ifes). In: OLIVEIRA, João F. et al. Políticas de acesso e expansão da educação superior: concepçôes e desafios. Brasília: INEP, 2006.

NUNES, B. Verdades e mentiras do Censo da Educação Superior. São Paulo, Revista Veja, 08 de novembro de 2011. Disponível em: <http://veja.abril.com.br/noticia/brasil/ verdades-e-mentiras-do-censo-da-educacao-superior>. Acesso em: 10 dez. 2011.

O ESTADÃO. Estudantes devem ter cuidado na hora de escolher o curso superior, 01 de junho de 2010. Disponível em: <http://www.estadao.com.br/noticias/vidae, estudantes-devem-ter-cuidado-na-hora-de-escolher-o-curso-superior,560099,0.htm>. Acesso em: 09 dez. 2011.

OLIVEIRA, J. F.; BITTAR, M. Ensino Superior noturno no Brasil: democratização do acesso, da permanência e da qualidade. In: CONGRESSO IBERO-BRASILEIRO DE POLÍTICA E ADMINISTRAÇÃO DA EDUCAÇÃO, 1., CONGRESSO LUSO-BRASILEIRO DE POLÍTICA E ADMINISTRAÇÃO DA EDUCAÇÃO, 6., CONGRESSO DO FÓRUM PORTUGUÊS DE ADMINISTRAÇÃO EDUCACIONAL, 4.,. Portugal/ Espanha, Anais... São Paulo: Anpae, 2010. Disponível em: <www.anpae.org.br/iberolusobrasileiro2010/cdrom/52.pdf>. Acesso em: 26 dez. 2012.

OLIVEIRA, J. F.; DOURADO, L. F.; AMARAL, N. C. Desafios e Perspectivas de uma Política para as Instituiçóes Federais de Ensino Superior (Ifes). In: OLIVEIRA, João F. et al. Políticas de acesso e expansão da educação superior: concepçôes e desafios. Brasília: INEP, 2006.

PIOVESAN, F. Ações afirmativas no Brasil: Desafios e perspectivas. In: CAMARGO, M. N. (Org.). Leituras Complementares de Constitucional. Direitos fundamentais. 2. ed. Salvador: Juspodivm, 2007.

SCHWARTZMAN, S. A questão da inclusão social na Universidade Brasileira. Trabalho científico apresentado no SIMPÓSIO UNIVERSIDADE E INCLUSÃO SOCIAL - EX- 
PERIÊNCIA E IMAGINAÇÃO, Mesa redonda "Inclusão Social na Universidade: uma questão pertinente?”, Universidade Federal de Minas Gerais, 24 de novembro de 2006. Disponível em: <http://www.schwartzman.org.br/simon/nclusao_ufmg.pdf >. Acesso em: 04 ago. 2010.

SGUISSARDI, V. Reforma universitária no Brasil - 1995-2006: precária trajetória e incerto futuro. Campinas, Educ. \& Soc., v. 27, n. 96 - Especial, p. 1021-1056, out., 2006.

. Universidade pública estatal: entre o público e o privado/mercantil. Campinas, Educ. \& Soc., v. 26, n. 90, p. 191-222, jan./abr., 2005.

. Privatização da educaçáo superior no Brasil 1995-2001. Revista de la Educación Superior, México, v. 31 (3), n. 123, p. 23-46, jul./set., 2002.

SORJ, B; MIRANDA, J. C.; MAGGIE, Y. Preâmbulo. In: FRY, P. et al. (Orgs.). Divisóes perigosas: políticas raciais no Brasil contemporâneo. Rio de Janeiro: Civilização Brasileira, 2007, p. 13-16.

TODOS PELA EDUCAÇÃO. Relatório De Olho nas Metas, 2011. Disponível em: <http:// www.todospelaeducacao.org.br//arquivos/biblioteca/de_olho_nas_metas_2011_tpe. pdf>. Acesso em: 18 fev. 2012.

UOL. EDUCAÇÃO. (2011a). Em seis anos, uma em cada três bolsas do ProUnifica ociosa. São Paulo, 23 jun. 2011. Disponível em: <http://educacao.uol.com.br/noticias/2011/06/23/ uma-em-cada-tres-bolsas-do-prouni-ficou-ociosa-entre-2005-e-2011.htm>. Acesso em: 18 jul. 2011.

. (2011b). Número de matriculados no ensino superior sobe $110 \% \mathrm{em} 10$ anos. São Paulo, 07 nov. 2011. Disponível em: <http://www1.folha.uol.com.br/saber/1002756-numero-de-matriculados-no-ensino-superior-sobe-110-em-10-anos.shtml>. Acesso em: 12 dez. 2011.

. ProUni tem 23\% de faculdades participantes com nota baixa. São Paulo, 20 jan. 2009. Disponível em: <http://educacao.uol.com.br/ultnot/2009/01/20/ult4528u548. jhtm>. Acesso em: 18 jul. 2011.

WEBER, D. MEC suspende vestibulares de 207 cursos superiores de baixa qualidade. O Globo/Educaçáo, 18 dez. 12. Disponível em: <http://oglobo.globo.com/ educacao/mec-suspende-vestibulares-de-207-cursos-superiores-de-baixa-qualidade-7085954\#ixzz36O5UjjLZ>. Acesso em: 24 dez. 2012.

ZAGO, N. Do acesso à permanência no Ensino Superior: Processos de estudantes universitários de camadas populares. Rio de Janeiro, Revista Brasileira de Educação, v. 11, n. 32, 2006, p. 226-237.

Recebido em 09 de agosto de 2014. Aprovado em 26 de maio de 2015.

DOI: http://dx.doi.org/10.1590/ES0101-7330201596208 